\title{
The effect of a commercial microbial phytase preparation on the in vitro release of phosphorus and amino acids from selected plant feedstuffs supplemented with free amino acids
}

\author{
S.M. Rutherfurd ${ }^{1}$, T.K. Chung ${ }^{3}$ and P.J. Moughan ${ }^{2}$ \\ 'Institute of Food, Nutrition and Human Health, \\ ${ }^{2}$ Riddet Centre, Massey University \\ Palmerston North, New Zealand \\ ${ }^{3}$ DSM Nutritional Products Asia Pacific Pte Ltd., Singapore
}

(Received 29 March 2004; revised version 25 June 2004; accepted 25 October 2004)

\begin{abstract}
A commercially available microbial phytase was investigated with the aim of firstly, determining its effectiveness in releasing phosphate from phytate and secondly, investigating the possible binding of supplemented amino acids to phytate and the effectiveness of microbial phytase in releasing bound amino acids. Feedstuffs with added synthetic amino acids were incubated in the presence or absence of microbial phytase and the resulting concentrations of free phosphate and free amino acids were determined. The mean dephosphorylation of phytate over all feedstuffs and reaction conditions used was 0.40 . Dephosphorylation ranged from 0 for wheat pollard to 0.84 for cottonseed meal depending on the feedstuff and the reactions conditions used. Incubation in the absence and presence of microbial phytase resulted in a recovery of supplemented amino acids of between 0.37 to 1.15 (mean $=0.84$ ) and 0.49 to 1.17 (mean $=0.89)$, respectively, depending on the amino acid, feedstuff and reaction conditions employed.
\end{abstract}

KEY WORDS: phytase, phytate, amino acid, in vitro degradation

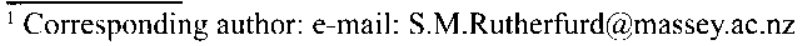




\section{INTRODUCTION}

Phytate (myo-inositol 1, 2, 3, 4, 5, 6 hexakis dihydrogen phosphate) is found at varying levels in almost all feedstuffs derived from plant material. Phytate also has the ability to bind minerals (Oberleas, 1973; Reddy et al., 1982), particularly divalent cations, lipids (Cosgrove, 1966), starch (Thompson and Yoon, 1984) and proteins (Cosgrove, 1980; Andersen, 1985; Thompson and Serraino, 1986). It is also possible that free amino acids, such as those supplemented in formulated diets for both pigs and poultry, form linkages with phytate lcading to a decreased digestibility of these supplemented amino acids. The phytate molecule itself is resistant to enzymatic digestion in the mammalian gut and while a small portion may be hydrolysed in poultry (Matyka et al., 1990; Edwards, 1993), most is not. Consequently, the phosphate contained within the phytate molecule is generally not nutritionally available and is excreted by the animal.

Phytase (myo-inositol-hexakisphosphate phosphohydrolase, EC 3.1.3.8) hydrolyses the phosphate moieties from the inositol ring. This enzyme is found naturally at varying levels in a number of plant materials. However, for many plant materials the amount of endogenous phytase present is too low to significantly improve the availability of nutrients complexed to phytate. For such feedstuffs, microbial phytase can be added to the feedstuff to enhance the release of phosphate (Edwards, 1992; Simons et al., 1992), minerals (Pallauf et al., 1992; Lei et al., 1994; Yi et al., 1994) and protein (Officer and Batterham, 1992; Mroz et al., 1994), from phytate. To date, the effect of added microbial phytase on the availability of synthetic amino acids added to feedstuffs has been largely overlooked. The current study aimed to investigate the role that microbial phytase may have, in firstly releasing phosphorus from phytate and secondly improving the availability of supplemented amino acids, when added to a wide range of plant-based feedstuffs.

\section{MATERIAL AND METHODS}

\section{Material}

Microbial phytase (RONOZYME ${ }^{6 i p}$ Phytase $^{\mathrm{CT}}$ ) was obtained from Nouozymes A/S, DK-2880 Bagavaerd, Denmark. The enzyme was a 3-phytase (E.C. 3.1.3.8) and was prepared from Aspergillus niger (gene origin) and produced by Aspergillus oryzae (production strain). Fifteen feedstuffs (rice bran, wheat bran, wheat pollard, copracake meal, maize, soyabean meal, peanut meal, cottonseed meal, sesameseed meal, rapeseed meal, rice, sunflowerseed meal, maize gluten meal, maize gluten feed and brewer's distiller dried grains) were obtained 
commercially. All feedstuffs were ground in the laboratory to $0.5 \mathrm{~mm}$ particle size. All other chemicals were analytical grade and were obtained from either Sigma Chemicals, St. Louis, Missouri or BDH Laboratory Supplies, Poole (England).

One phytase unit FYT is defined as the amount of enzyme that liberates $1 \mu \mathrm{mol}$ of inorganic orthophosphate per minute at $\mathrm{pH} 5.5,37^{\circ} \mathrm{C}$ using a sodium phytate $\left(\mathrm{C}_{6} \mathrm{H}_{8} \mathrm{Na}_{12} \mathrm{O}_{24} \mathrm{P}_{6} \cdot 10 \mathrm{H}_{2} \mathrm{O}\right)$ concentration of $0.005 \mathrm{~mol} / \mathrm{L}$.

\section{Incubation conditions}

Each feedstuff was subjected to the following incubation treatment and each treatment was conducted in duplicate. To $1 \mathrm{~g}$ of each feedstuff was added 9.6 $\mathrm{ml}$ of $0.1 \mathrm{M}$ acetate buffer containing $0.01 \%$ Tween 20 , adjusted to either $\mathrm{pH}$ 2.5 or 5.5 and $0.4 \mathrm{ml}$ of an amino acid solution containing $13.6 \mathrm{mg}$ lysine, 11.3 $\mathrm{mg}$ threonine, $6.4 \mathrm{mg}$ methionine and $2.9 \mathrm{mg}$ tryptophan. Lysine was added to give a final total (free + bound) lysine to phytate ratio of between 3 and 4 based on the average lysine content of the 15 feedstuffs. This ratio was used since in a standard poultry diet the ratio of lysine to phytate would normally be within this range. The other supplemented amino acids were added such that the ratio of these amino acids to lysine would be similar to that present in an ideal protein for the chicken (Baker and Han, 1994; Emmert and Baker, 1997). For each incubation $\mathrm{pH}$ ( 2.5 and 5.5$)$, microbial phytase was added to each flask to give either $0,500,1000$ or 2000 phytase units (FYT) of microbial phytase per kg of feedstuff. All the test flasks were then incubated in a forced air oven at $37^{\circ} \mathrm{C}$ for $4 \mathrm{~h}$ during which time the flasks were stirred constantly using a magnetic stirring plate. After incubation the flasks were removed and $10 \mathrm{ml}$ of stop solution $(0.5 \mathrm{M} \mathrm{HCl})$ was added to each flask to prevent further enzyme activity. A further two flasks, for each feedstuff, were used to determine the extent of amino acid binding prior to any incubation. These flasks were not incubated and had the $10 \mathrm{ml}$ of stop solution added prior to the acetate buffer and amino acid solution and no microbial phytase was added. The contents of each flask were filtered through Whatman No 1 filter paper and stored at $-20^{\circ} \mathrm{C}$ prior to analysis for free phosphate and free amino acids.

The free phosphate content of the solution was analysed by taking between 0.05 and $0.2 \mathrm{ml}$ of filtrate and diluting to $5 \mathrm{ml}$ with water. Ammomium molybdate solution $(1 \mathrm{ml})$ was added and the contents of the tubes were mixed thoroughly, then $0.2 \mathrm{ml}$ of amino-napthol sulphonic acid solution was added and the tube contents were mixed thoroughly again. The tubes were allowed to stand for 30 $\min$ before the absorbance was read at $680 \mathrm{~nm}$. The free phosphate content was quantified by comparison of the absorbance value obtained for each sample with that determined for a range of phosphate solutions (potassium dihydrogen phosphate) of known concentration. 
The proportion of phytate dephosphorylated was calculated using the following equation:

Phytate dephosphorylated $=\frac{(\text { Free phosphate }}{\left.\text { (incubared feedsuff) }- \text { Free phosphate }_{\text {(original feedsuff) }}\right)}$

The units for the free phosphate in the incubated and original feedstuffs and the phosphate content of the phytate were $\mathrm{g} / 100 \mathrm{~g}$ of feedstuff.

\section{Free amino acid analysis}

Free amino acids in the solutions before and after incubation were determined by firstly adding norleucine, which was used as an internal standard, and sufficient $140 \mathrm{mM}$ sodium citrate buffer $\mathrm{pH} 2.0$ to give a final concentration of $70 \mathrm{mM}$ sodium citrate. The mixture was then ultrafiltered using a Vivaspin concentrator $(5000 \mathrm{MWCO})$. The free amino acids in the ultrafiltrate were separated using a Waters ion-exchange HPLC system, and detected, after post-column ninhydrin derivatization, by measuring absorbance at $570 \mathrm{~nm}$.

The average analytical error between duplicates when determining unbound phosphate and free amino acid content was \pm 2.2 and $\pm 3.1 \%$, respectively.

\section{Phytate P determination}

The phytate $\mathrm{P}$ concentration in each original feedstuff was determined based on the method of Selle (1996). Phytate was first extracted by incubating the feedstuff in a $\mathrm{HCl} / \mathrm{Na}_{2} \mathrm{SO}_{4}$ solution at room temperature for $3 \mathrm{~h}$ with constant stirring. The extract was then filtered through Whatman No. 1 filter paper, an aliquot then taken and diluted with deionised water. The solution was then heated in a boiling waterbath in the presence of $\mathrm{FeCl}_{3}$ for $20 \mathrm{~min}$ to precipitate the phytate. The precipitate was centrifuged and any precipitated inorganic phosphate was redissolved by resuspending the pellet in a $\mathrm{Na}_{2} \mathrm{SO}_{4}$ /dilute acid solution. The suspension was recentrifuged and the pellet dissolved in sulphuric acid prior to digestion in sulphuric acid, nitric acid and water $(1: 1: 1)$ for $90 \mathrm{~min}$. The digest was then diluted with water and heated in a boiling waterbath for $15 \mathrm{~min}$. The $\mathrm{pH}$ of the solution was adjusted to approximately 1-2 and then made up to volume with water. The phosphate content of the solution was then determined as described above. For the determination of the phytate $\mathrm{P}$ content for feedstuffs either prior to incubation or after incubation either with or without microbial phytase, the mean analytical error between duplicate analyses was $\pm 2.1 \%$. 


\section{RESULTS}

The determined phytate $\mathrm{P}$ contents of the 15 feedstuffs are shown in Table 1 .

TABLE

Phytate $\mathrm{P}$ content for 15 selected feedstuffs, $\mathrm{g} / \mathrm{kg}$

\begin{tabular}{lc}
\hline Feedstuff & ${\text { Phytate P } \text { content }^{1}}^{1}$ \\
\hline Rice bran & 18.6 \\
Sunflower meal & 11.5 \\
Rapeseed meal & 9.1 \\
Wheat pollard & 7.9 \\
Cottonseed meal & 7.7 \\
Wheat bran & 7.6 \\
Maize gluten feed & 6.9 \\
Sesameseed meal & 6.2 \\
Peanut meal & 4.3 \\
Maize gluten meal & 3.9 \\
Brewer's distiller dried grains & 3.8 \\
Soyabean meal & 3.4 \\
Copracake meal & 3.4 \\
Maize & 2.0 \\
Rice & 0.6 \\
\hline
\end{tabular}

' means of duplicate determinations. Differences between duplicates were set at $5 \%$, if the differences were greater than $5 \%$ the analysis was repeated

The phytate $P$ levels ranged from $0.6 \mathrm{~g} / \mathrm{kg}$ for rice to $18.6 \mathrm{~g} / \mathrm{kg}$ for rice bran. The free phosphate was measured in each of the original feedstuffs and in each feedstuff after incubation with varying amounts of microbial phytase. The proportion of phytate dephosphorylated after each incubation was then calculated. The results are shown in Table 2.

For most feedstuffs there was little dephosphorylation (less than $5 \%$ ) of phytate after incubation in the absence of microbial phytase at $37^{\circ} \mathrm{C}$ for $4 \mathrm{~h}$ at either $\mathrm{pH} 2.5$ or 5.5. In contrast, for wheat bran, wheat pollard and rice between 0.65 and 0.84 dephosphorylation occurred.

When the wheat bran, wheat pollard and rice were incubated with 500 FYT microbial phytase per $\mathrm{kg}$ of feedstuff a further $0.03-0.22$ of the phytate was dephosphorylated. When additional microbial phytase was included in the incubation mixture, at best, only a further 0.11 units of phytate was further dephosphorylated. For copracake meal and maize, approximately 0.60 of the phytate present was dephosphorylated after incubation with microbial phytase (500 FYT $/ \mathrm{kg})$. This increased only slightly $(0.03-0.13)$ after incubation with greater amounts of 
TABLE 2

Phytate degraded ${ }^{1}$ after incubation with either $0,500,1000$ or $2000 \mathrm{FYT}^{2}$ microbial phytase (RONOZYMETM Phytase) per kg of feedstuff ${ }^{3}$

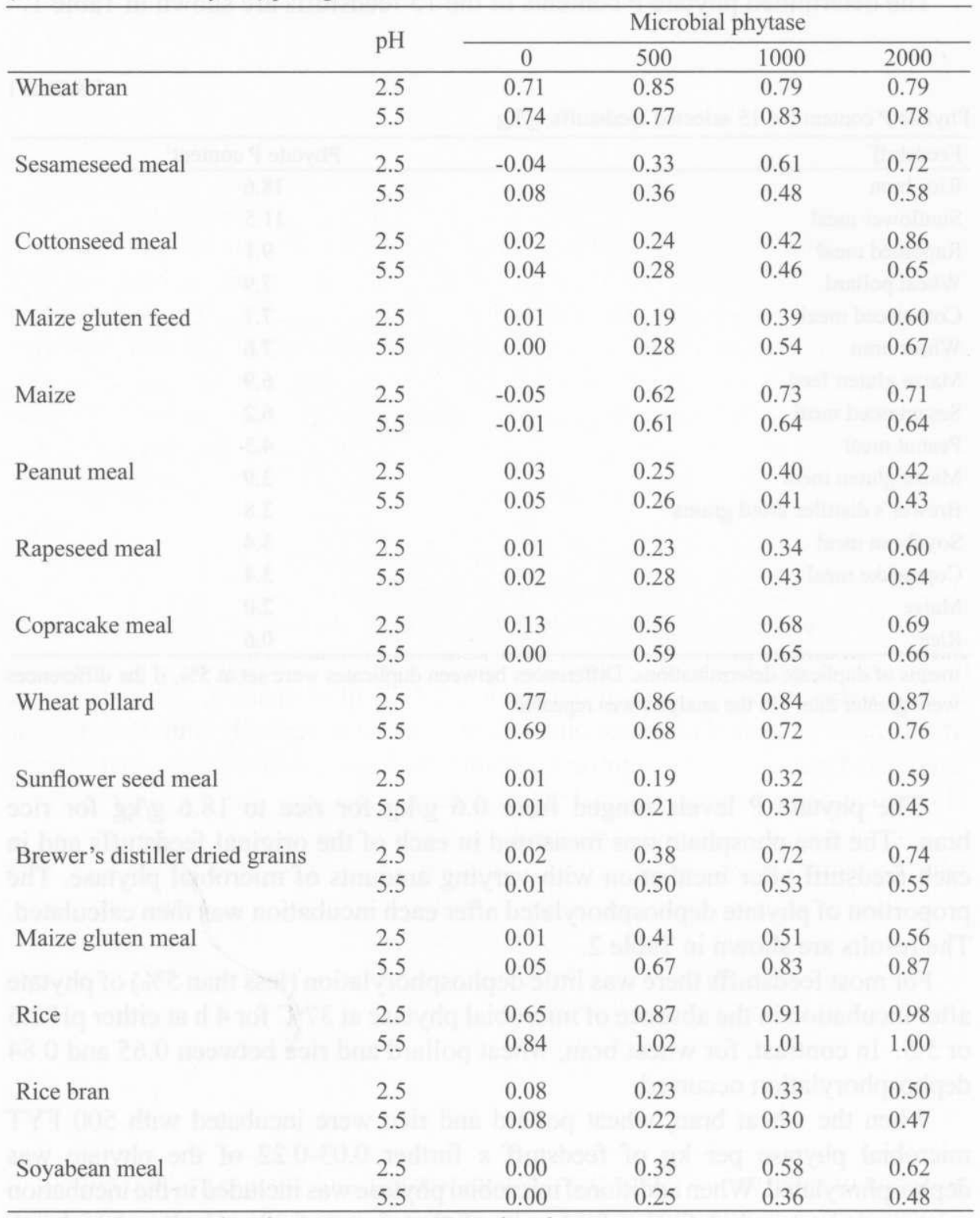

${ }^{1}$ calculated as $\frac{\text { Free phosphate }}{\text { incubated feedsuff }}$ - Free phosphate original feedstuff

${ }^{2} \mathrm{FYT}=$ phytase units

Phosphate content of phytate

${ }^{3}$ differences between duplicates were set at $5 \%$, if the differences were greater than $5 \%$ the analysis was repeated 
microbial phytase. For peanut meal, sesameseed meal, brewer's distiller dried grains and maize gluten meal, incubation with enzyme $(500 \mathrm{FYT} / \mathrm{kg})$ resulted in a 0.25 0.67 dephosphorylation of phytate. After incubation with $1000 \mathrm{FYT} / \mathrm{kg}$ phytase, a further $0.03-0.34$ of the phytate was dephosphorylated while with $2000 \mathrm{FYT} / \mathrm{kg}$ microbial phytase there was only a further 0.11 dephosphorylation. For the remaining feedstuffs (cottonseed meal, maize gluten feed, rapeseed meal, sunflowerseed meal, rice bran and soyabean meal) the amount of phytate dephosphorylation increased almost linearly with increasing microbial phytase inclusion.

The recovery of the supplemented amino acids in the incubation mixture prior to any incubation was between 0.37 and 1.15 (Figure 1). Overall, most ( $85 \%)$ of the recoveries of the supplemented amino acids prior to any incubation were less than 1.00 , but there were a number that were higher than 1.00 , possibly due to the release of intrinsic amino acids bound to compounds in the feedstuff. The mean recovery for all of the amino acids tested at $\mathrm{pH} 2.5$ and 5.5 was 0.82 and 0.85 , respectively.

For almost all the feedstuffs tested, incubation in the absence of microbial phytase did not greatly alter the recovery of the supplemented amino acids (Figure 1). The exceptions were peanut meal, wheat pollard and rice, where the mean recovery of the supplemented amino acids rose from 0.65 prior to incubation to 0.77 after incubation without microbial phytase when the incubation was carried out at $\mathrm{pH} 2.5$. In contrast, when the incubation was carried out at $\mathrm{pH} 5.5$, the mean recovery of the supplemented amino acids decreased somewhat from 0.71 prior to incubation to 0.61 after incubation without microbial phytase. For rice bran there was a general increase in the amino acid recovery from 0.72 prior to incubation to 0.95 after incubation in the absence of microbial phytase. For maize gluten feed, there was generally little difference in amino acid recoveries either prior to or after incubation without microbial phytase (1.02 prior to incubation compared to 0.98 after incubation).

For wheat bran, cottonseed meal, rapeseed meal, maize, copracake meal, wheat pollard, maize gluten feed, peanut meal, rice and soyabean meal there was no meaningful change in the recovery of the supplemented amino acids after incubating the feedstuff in either the presence or absence of microbial phytase at pH 2.5. Moreover, for wheat bran, cottonseed meal, rapeseed meal, copracake meal, wheat pollard, rice and soyabean meal, rice bran, brewer's distiller dried grains and sunflowerseed meal there was no meaningful change in the recovery of the supplemented amino acid after incubating the feedstuff in either the presence or absence of microbial phytase at $\mathrm{pH} 5.5$.

When the sesameseed meal-amino acid mixture was incubated at $\mathrm{pH} 2.5$ in the presence of microbial phytase there was no meaningful change in the recovery of threonine, methionine and lysine. However, the recovery of tryptophan decreased by approximately 0.17 and 0.23 . After incubation at $\mathrm{pH} 5.5$ with increasing levels of microbial phytase, there was a corresponding increase in the recovery of most of the amino acids determined. 

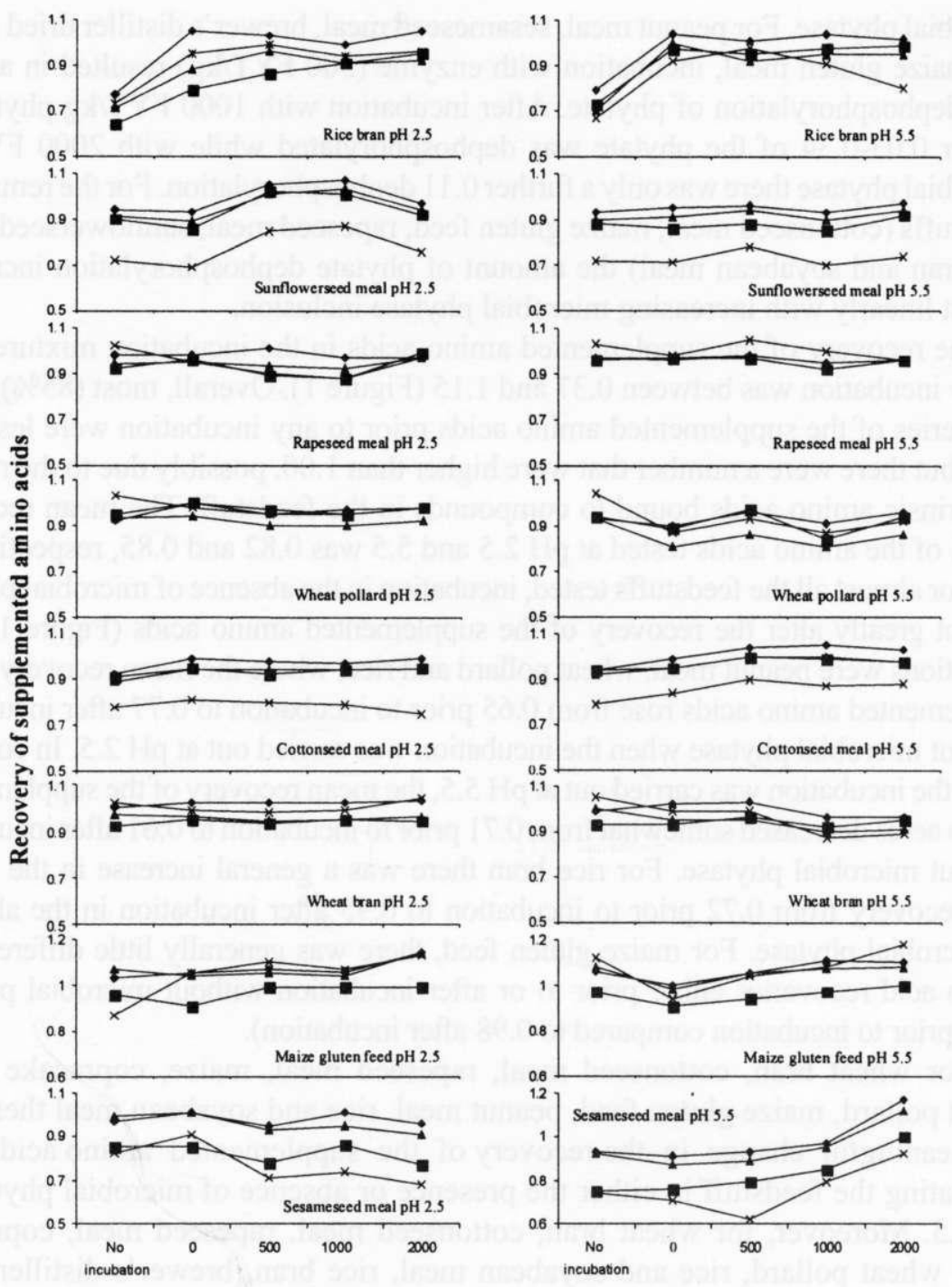

Phytase inclusion, FYT/kg feedstuff

Figure 1a. The recovery ${ }^{1}$ of supplemented threonine $\boldsymbol{\bullet}$, methionine $\boldsymbol{\Delta}$, tryptophan $\boldsymbol{\boldsymbol { a }}$ and lysine $\times$, either prior to incubation (no incubation) and after incubation ${ }^{2}$ with either $0,500,1000,2000 \mathrm{FYT}^{3}$ microbial phytase added per $\mathrm{kg}$ of feedstuff

${ }^{1}$ the recovery was calculated as follows:

amount of free amino acid in the incubation solution after incubation

amount of free amino acid added to the feedstuff-amino acid solution

${ }^{2}$ incubation condition were for $4 \mathrm{~h}$ at $37^{\circ} \mathrm{C}$ at either $\mathrm{pH} 2.5$ or 5.5 with constant stirring

${ }^{3} \mathrm{FYT}=$ Phytase units

${ }^{4}$ differences between duplicates were set at $5 \%$, if the differences were greater than $5 \%$ the analysis was repeated 

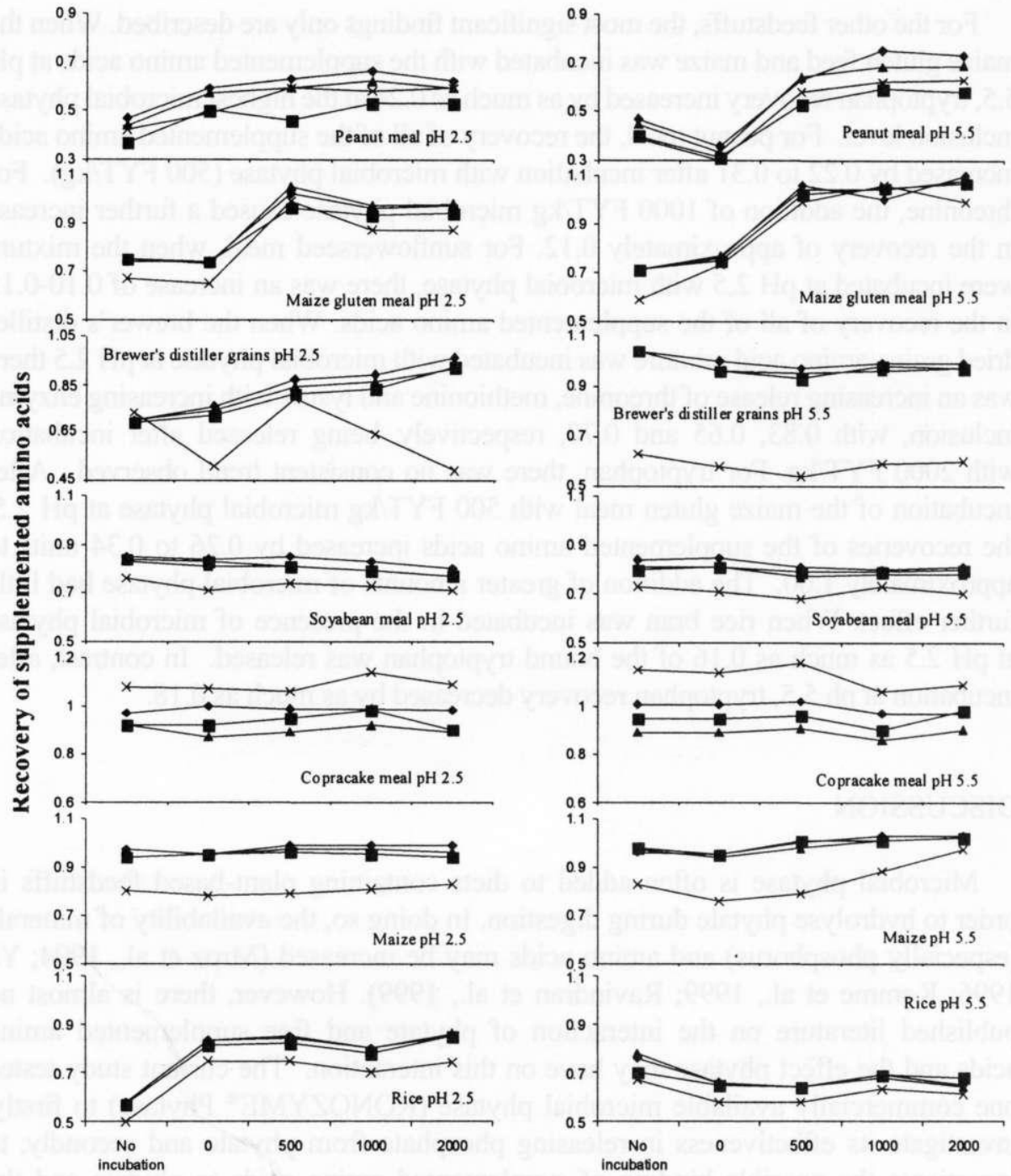

Phytase inclusion, FYT/kg feedstuff

Figure $1 \mathrm{~b}$. The recovery ${ }^{1}$ of supplemented threonine $\boldsymbol{\Delta}$, methionine $\boldsymbol{\Lambda}$, tryptophan $\mathbf{\boldsymbol { a }}$ and lysine $\times$, either prior to incubation (no incubation) and after incubation ${ }^{2}$ with either $0,500,1000,2000 \mathrm{FYT}^{3}$ microbial phytase added per $\mathrm{kg}$ of feedstuff ${ }^{4}$ 
For the other feedstuffs, the most significant findings only are described. When the maize gluten feed and maize was incubated with the supplemented amino acids at $\mathrm{pH}$ 5.5 , tryptophan recovery increased by as much as 0.24 at the highest microbial phytase inclusion level. For peanut meal, the recovery of all of the supplemented amino acids increased by 0.22 to 0.31 after incubation with microbial phytase $(500 \mathrm{FYT} / \mathrm{kg})$. For threonine, the addition of $1000 \mathrm{FYT} / \mathrm{kg}$ microbial phytase caused a further increase in the recovery of approximately 0.12 . For sunflowerseed meal, when the mixture were incubated at $\mathrm{pH} 2.5$ with microbial phytase, there was an increase of $0.10-0.15$ in the recovery of all of the supplemented amino acids. When the brewer's distiller dried grains-amino acid mixture was incubated with microbial phytase at $\mathrm{pH} 2.5$ there was an increasing release of threonine, methionine and lysine with increasing enzyme inclusion, with $0.83,0.65$ and 0.70 , respectively, being released after incubation with $2000 \mathrm{FYT} / \mathrm{kg}$. For tryptophan, there was no consistent trend observed. After incubation of the maize gluten meal with $500 \mathrm{FYT} / \mathrm{kg}$ microbial phytase at $\mathrm{pH} 2.5$, the recoveries of the supplemented amino acids increased by 0.26 to 0.34 units to approximately 1.00 . The addition of greater amounts of microbial phytase had little further effect. When rice bran was incubated in the presence of microbial phytase at $\mathrm{pH} 2.5$ as much as 0.16 of the bound tryptophan was released. In contrast, after incubation at ph 5.5 , tryptophan recovery decreased by as much as 0.18 .

\section{DISCUSSION}

Microbial phytase is often added to diets containing plant-based feedstuffs in order to hydrolyse phytate during digestion. In doing so, the availability of minerals (especially phosphorus) and amino acids may be increased (Mroz et al., 1994; Yi, 1996; Kemme et al., 1999; Ravindran et al., 1999). However, there is almost no published literature on the interaction of phytate and free supplemented amino acids and the effect phytase may have on this interaction. The current study tested one commercially available microbial phytase (RONOZYME ${ }^{\text {ki) }}$ Phytase) to firstly, investigate its effectiveness in releasing phosphate from phytate and secondly, to investigate the possible binding of supplemented amino acids to phytate and the effectiveness of microbial phytase in reversing this binding. The determination of phytate dephosphorylation, although being indirect, was relatively straightforward in that the inorganic (free or unbound) phosphate of the feedstuff was determined before and after in vitro incubation with varying amounts of added microbial phytase, and the difference between these determinations in phosphate content was most likely a result of the dephosphorylation of phytate. Investigating the amino acid binding to phytate and release by the action of phytase was not so straightforward. Again a difference method was used, where the free amino acid content of the supplemented feedstuffs was determined before and after incubation with varying levels of microbial phytase. 
It was assumed that any loss of the free amino acids in solution was due to the binding of these amino acids to compounds in the feedstuff, of which one of these compounds could be phytate. Any increase in the free amino acid content after incubation with microbial phytase was possibly due to the action of microbial phytase in releasing the amino acids bound to phytate, through dephosphorylation of phytate. The in vitro system used in this study was not designed to mimic in vivo digestion in the gut. Indeed, the inclusion of gut enzymes, particularly proteases would have caused the hydrolysis of protein in the feedstuffs, which in turn would have interfered with the determination of the free amino acid content of the reaction mixtures.

In general the addition of microbial phytase appeared to increase phytate hydrolysis. Wheat bran, wheat pollard and rice were the exception. Wheat and wheat by-products are known to contain large quantities of intrinsic phytase (McCance and Widdowson, 1944; Bartnik and Szafranska, 1987) which may have been responsible for the phytate dephosphorylation in the absence of microbial phytase. In contrast, rice is not known to contain large amounts of intrinsic phytase, however, given that rice contains very low levels of phytate $(0.21 \%)$, it is possible that a high proportion of the phytate in rice can be dephosphorylated by the small amount of intrinsic phytase present. For the remaining feedstuffs (including rice) there is anecdotal evidence that there is a relationship between the level of phytate present in the feedstuff and the amount of microbial phytase required to achieve maximal dephosphorylation of phytate (Table 3), where increasing phytate content in the feedstuff required more microbial phytase to achieve maximal phytate dephosphorylation. If this relationship does exist then this may have ramifications for the pig and poultry feed

TABLE 3

Phytate $P$ content ${ }^{1}(\mathrm{~g} / \mathrm{kg}$ ) of the non-wheat based feedstuffs and the microbial phytase level (FYT/kg feedstuff) where maximum in vitro phytate degradation occurred

\begin{tabular}{lcc}
\hline Feedstuff & Phytate P & $\begin{array}{c}\text { Microbial phytase (FYT/kg) } \\
\text { required for maximum phytate } \\
\text { degradation }\end{array}$ \\
\hline Rice bran & 18.6 & $>1000$ \\
Sunflower meal & 11.5 & $>1000$ \\
Rapeseed meal & 9.1 & $>1000$ \\
Cottonseed meal & 7.7 & $>1000$ \\
Maize gluten feed & 6.9 & $>1000$ \\
Sesameseed meal & 6.2 & $>1000$ \\
Peanut meal & 4.3 & $500-1000$ \\
Maize gluten meal & 3.9 & $500-1000$ \\
Brewer's distiller dried grains & 3.8 & $500-1000$ \\
Soyabean meal & 3.4 & $500-1000$ \\
Copracake meal & 3.4 & $<500$ \\
Maize & 2.0 & $<500$ \\
Rice & 0.6 & $<500$ \\
\hline
\end{tabular}

'differences between duplicates were set at $5 \%$, if the differences were greater than $5 \%$ the analysis was repeated 
industries in that rather than having a set microbial phytase inclusion level for diet formulation, perhaps graded inclusion levels should be used depending on phytate content of the diet, to maximize the effectiveness of microbial phytase and to avoid resource wastage. The form and quantitative description of this apparent relationship may warrant further investigation.

It is interesting to note that while maximal phytate dephosphorylation was achieved for a large number of the feedstuffs used in this experiment, rice was the only product for which the dephosphorylation of phytate appeared to be complete. For all other feedstuffs, where maximal dephosphorylation was achieved, between approximately 15 and $50 \%$ of the phytate $P$ was not recovered as free phosphate. The phytase used in this study incompletely catalyses the dephosphorylation of phytate with the end product being myo-inositol-2-monophosphate (Wyss et al., 1999). While this is consistent with the maximal recovery of free phosphate of $85 \%$ observed for the wheat bran and pollard and the maize gluten meal but would not explain the much lower recoveries of phosphate (as low as 50\%) observed for many of the feedstuffs. In these cases, steric hindrance may reduce the efficiency of the phytase.

The effectiveness of microbial phytase in dephosphorylating phytate was investigated using two different $\mathrm{pH}$ 's (2.5 and 5.5). It would appear that the incubation $\mathrm{pH}$ for which microbial phytase is most effective in dephosphorylating phytate may be affected by the type of feedstuff.

Feedstuffs are complex materials containing a multitude of compounds with highly diverse chemical characteristics. Many feedstuffs contain a variety of compounds that under certain conditions can bind to nutrients present in the feedstuffs or mixed diets. Synthetic amino acids used in the supplementation of diets are highly valuable nutrients that possess a range of reactive functional groups. Some of these groups are capable of binding by either direct chemical bonds or associative complexes, to many compounds present in feedstuffs (Hurrell and Carpenter, 1981), including phytate. There appears, from the present study using an in vitro incubation, to be no clear overall trend with respect to the binding of amino acids to compounds in the feedstuffs at either of the incubation pH's tested. Despite this, there are some observations that can be made; firstly, for most of the feedstuffs, some or all of the supplemented amino acids appeared to bind to compounds within the feedstuffs. Secondly, where binding did occur, for most feedstuffs the same amino acids bound regardless of $\mathrm{pH}$, although the extent of binding was not always the same. For wheat bran, rapeseed meal and copracake meal there was no binding, consequently there would be no benefit of adding microbial phytase to these feedstuffs. The feedstuffs for which binding of the supplemented amino acids to compounds in the feedstuff appeared to occur, but for which microbial phytase had no apparent effect on releasing these amino acids were rapeseed meal, wheat pollard, rice and soyabean meal. The feedstuffs for which microbial phytase appeared to cause the release of some if not all of the bound supplemented amino acids at $\mathrm{pH} 2.5$ were sunflowerseed meal, brewer's 
distiller dried grains, maize gluten meal and rice bran, while at $\mathrm{pH} 5.5$ the feedstuffs were sesameseed meal, cottonseed meal, maize gluten feed, maize, peanut meal and maize gluten meal. It must be considered that this study was conducted using an in vitro system. It is possible that the results obtained here may differ from those observed in vivo. A logical next step for this research would be to investigate the role that microbial phytase has in improving the availability of supplemented amino acids when applied to an in vivo system. The advantage of the in vitro system is that it is relatively rapid and inexpensive to perform, however the accuracy of this system needs to be validated against in vivo experiments. The in vitro system may prove to be a useful tool in the future for determining the extent to which microbial phytase is able to degrade phytate in plant based feedstuffs.

\section{REFERENCES}

Andersen P.A., 1985. Interactions between proteins and constituents that affect protein quality. In: G.W. Finley, D.T Hopkins (Editors). Digestibility and Amino Acid Availability in Cereals and Oilseeds. American Association of Cereals Chemists, St. Paul, Minnesota, pp. 31-45

Baker D.H., Han Y., 1994. Ideal amino acid profile for chicks during the first three weeks post hatching. Poultry Sci. 73, 1441-1447

Bartnik M., Szafranska I., 1987. Changes in phytate content and phytase activity during germination of some cereals. J. Cereal Sci. 5, 23-28

Cosgrove D.J., 1966. The chemistry and biochemistry of inositol polyphosphates. Rev. Pure Appl. Chem. 16, 209-224

Cosgrove D.J., 1980. Inositol Phosphates: Their Chemistry, Biochemistry and Physiology. Elsevier Scientific Publishing Co., New York

Edwards H.M. Jr., 1992. Minimising phosphorus excretion in poultry. In: Proceedings of the Georgia Nutrition Conference for the Feed Industry. Atlanta, pp. 124-131

Edwards H.M. Jr., 1993. Dietary 1,25-dihydroxycholecalciferol supplementation increases natural phytate phosphorous utilization in chickens. J. Nutr. 123, 567-577

Emmert J.L., Baker D.H., 1997. Use of the ideal protein content for precision formulation of amino acid levels in broiler diets. J. Appl. Poultry Res. 6, 462-470

Hurrell R.F., Carpenter K.J., 1981. The estimation of available lysine in foodstuffs after Maillard reactions. In: L. Eriksson (Editor). Progress in Food and Nutrition Science. Maillard Reactions in Food. Pergamon Press, Oxford, pp. 159-176

Kemme P.A., Jongbloed A.W., Mroz Z., Kogut J., Beynen A.C., 1999. Digestibility of nutrients in growing-finishing pigs is affected by Aspergillus niger phytase, phytate and lactic acid levels. Livest. Prod. Sci. 58, 107-117

Lei X.G., Ku P.K., Miller E.R., Yokoyama M.T., Ullrey D.E., 1994. Calcium levels affects the efficacy of supplemental microbial phytase in maize-soybean meal diets of weanling pigs. J. Anim. Sci. 72, 139-143

Maddaiah V.T., Kurnick A.A., Reid B.L., 1964. Phytic acid studies. Proc. Soc. Exp. Biol. Med. 115, 391-393

Matyka S., Korol W., Bogusz G., 1990. The retention of phytin P from diets with fat supplements in broiler chicks. Anim. Feed Sci. Tech. 31, 223-230

McCance R.A., Widdowson E.M., 1944. Activity of the phytase in different cereals and its resistance to dry heat. Nature (London) 153, 650 
Mroz Z., Jongbioed A.W., Kemme P.A., 1994. Apparent digestibility and retention of nutrients bound to phytate complexes as influenced by microbial phytase and feeding regimen in pigs. J. Anim. Sci. 72, 126-132

Oberleas D., 1973. Phytates. In: Toxicants Occurring Naturally in Foods. National Academy of Sciences, Washington, DC, pp. 363-371

Officer D.I., Batterham E.S., 1992. Fnzyme supplementation of linola ${ }^{\mathrm{TM}}$ meal for growing pigs. Proc. Aust. Soc. Anim. Prod. 19, 288

Pallauf J., Höhler D., Rimbach G., Neusser H., 1992. Einfluss einer Zulage an mikrobieller Phytase zu einer Mais-Soja-Diät auf die scheinbare. Absorption von Phosphor und Calcium beim Ferkel. J. Anim. Physiol. Anim. Nutr. 67, 30-40

Ravindran V., Cabahug S., Ravindran G., Bryden W.L., 1999. Influences of microbial phytase on apparent ileal amino acid digestibility of feedstuffs for broilers. Poultry Sci, 78, 699-706

Reddy N.R., Balakrishnan C.V., Salunkhe D.K., 1982. Phytates in legumes. Adv. Food Res. 28, 1-92

Selle P.I., Ravindran V., Cadogan O.T., Walker II.R., Bryden W.L., 1996. The role of microbial phytase in poultry and pig nutrition. In: Proceedings of the $10^{\text {th }}$ Australian Poultry and Feed Convention, Melbourne. World's Poultry Science Association (Australian Branch), Melbourne (Australia), pp. 219-224

Simons P.C.M., Jongbloed A.W., Versteegh H.A.J., Kemme P.A., 1992. Improvement of phosphorus availability by microbial phytase in poultry and pigs. In: Proceedings of the Georgia Nutrition Conference for the Feed Industry, Atlanta, pp. 100-109

Thompson L.U., Serraino M.R., 1986. Effect of phytic acid reduction on rapeseed protein digestibility and amino acid absorption. J. Agr. Food Chem. 34, 468-469

Thompson L.U., Yoon J.H., 1984. Starch digestibility as affected by polyphenols and phytic acid. J. Food Sci. $49,1228-1229$

Wyss M., Brugger R., Kronenberger A., Rémy R., Fimbel R., Oesterhelt G., Lehmann M., van Loon A.P.G.M., 1999. Biochemical characterization of fungal phytases (myo-inositol hexakisphosphate phosphohydrolases): catalytic properties. Appl. Environ. Microbiol. 65, 367-373

Yi Z., Koregay E.T., Denbow D.M., 1996. Effect of microbial phytase on nitrogen an amino acid digestibility and nitrogen retention of turkey poults fed maize-soybean meal diets. Poultry Sci. $75,979-990$

Yi Z., Koregay E.T., McGuirk A., 1994. Replacement values of inorganic phosphorus by microbial phytase for pigs and poultry. J. Anim. Sci. 72, Suppl. 1, 330

\section{STRESZCZENIE}

\section{Wplyw dodatku handlowego preparatu fitazy mikrobiologicznej na uwalnianie fosforu i aminokwasów in vitro $\mathrm{z}$ wybranych pasz roślinnych uzupełnionych wolnymi aminokwasami}

Celem badań było oznaczenie: 1. wpływu dodanego do pasz handlowego preparatu fitazy mikrobiologicznej na wchłanianie fosforanów z fitynianów, a także 2 . moźliwości wiązania dodanych aminokwasów z fitynianami oraz efektywność działania fitazy mikrobiologicznç w uwalnianiu związanych aminokwasów.

Pasze $\mathrm{z}$ dodanymi aminokwasami inkubowano w obecności lub bez dodatku fitazy mikrobiologicznej i oznaczano stężenie wolnych fosforanów i aminokwasów. Średnia defosforyzacja fitynianów dla wszystkich pasz i sposobów postępowania wynosiła 0,40 . Defosforyzacja wahała się od 0 dla otrąb pszennych do 0.84 dla śruty bawełnianej. Otrzymane wyniki zależały od rodzaju paszy i sposobu postçpowania. Odzyskanie dodanych aminokwasów po inkubacji bez lub z dodatkiem fitazy mikrobiologicznej wahało się od 0,37 do 1,15 (średnio 0,84 ) i od 0,49 do 1,17 (średnio 0,89 ), odpowiednio, w zależności od aminokwasu, paszy i warunków inkubacji. 